\begin{tabular}{|c|c|c|}
\hline $\begin{array}{l}\text { JURNAL } \\
\text { INOVASI } \\
\text { TEKNOLOGI } \\
\text { PENDIDIKAN }\end{array}$ & $\begin{array}{l}\text { Jurnal Inovasi Teknologi Pendidikan } \\
\text { Volume 4, No 2, October } 2017 \text { (186-200) } \\
\text { Online: http:/ /journal.uny.ac.id/index.php/jitp }\end{array}$ & $\begin{array}{l}\text { Ikatan Profesi Teknologi } \\
\text { Pendidikan Indonesia }\end{array}$ \\
\hline
\end{tabular}

\title{
PELAKSANAAN PEMBELAJARAN KURIKULUM 2013 DI SD NEGERI SERAYU YOGYAKARTA
}

\author{
Lalu Wirya Artapati, C Asri Budiningsih \\ Program Pascasarjana, Universitas Negeri Yogyakarta \\ wirya.uny@gmail.com, asri_budi@yahoo.co.id
}

\begin{abstract}
Abstrak
Penelitian ini bertujuan untuk mendeskripsikan: (a) perencanaan pembelajaran pada Kurikulum 2013, (b) pelaksanaan pembelajaran pada Kurikulum 2013, (c) penilaian hasil belajar Kurikulum 2013, dan (d) hambatan dalam pelaksanaan pembelajaran Kurikulum 2013 yang seluruhnya dilaksanakan di SD Negeri Serayu Yogyakarta. Subjek penelitian ini terdiri dari kepala sekolah, wakil kepala sekolah bidang kurikulum, guru, siswa, dan orang tua siswa. Pengumpulan data dilakukan melalui observasi partisipan, wawancara mendalam, dan dokumentasi. Keabsahan data dilakukan dengan cara ketekunan pengamatan dan triangulasi data. Data penelitian ini dianalisis secara terus-menerus sejak awal pengumpulan data. Pada prosesnya terdiri dari tiga tahapan yang saling terkait yaitu reduksi data, penyajian data, dan pengambilan kesimpulan. Hasil penelitian mengungkapkan empat temuan. Pertama, RPP yang dikembangkan oleh guru-guru di SD Negeri Serayu Yogyakarta telah disusun dengan detail berdasarkan tema dan subtema tertentu yang mengacu pada silabus Kurikulum 2013. Kedua, Pelaksanaan pembelajaran yang dilakukan guru-guru meliputi kegiatan pendahuluan, kegiatan inti, dan kegiatan penutup. Ketiga, penilaian hasil belajar yang dilakukan guru-guru di SD Negeri Serayu Yogyakarta antara lain menggunakan penilaian sikap, pengetahuan, dan keterampilan. Penilaian dilakukan dengan, antara lain: tes dan non tes dalam bentuk tertulis maupun lisan, pengamatan kinerja, pengamatan sikap, penilaian hasil karya berupa tugas, proyek, penggunaan portofolio, dan penilaian diri. Keempat, hambatan yang dihadapi dalam pelaksanaan Kurikulum 2013 antara lain: banyaknya materi namun alokasi waktunya sedikit, penilaian pembelajaran terlalu banyak yang mengakibatkan guru kerepotan.

Kata kunci: Kurikulum 2013, pelaksanaan pembelajaran.
\end{abstract}

\section{LEARNING IMPLEMENTATION OF 2013 CURRICULUM AT SERAYU ELEMENTARY SCHOOL}

\author{
Lalu Wirya Artapati, C Asri Budiningsih \\ Program Pascasarjana, Universitas Negeri Yogyakarta \\ wirya.uny@gmail.com, asri_budi@yahoo.co.id
}

\begin{abstract}
This study aimed to describe: (a) learning plan of 2013 curriculum, (b) learning implementation of 2013 curriculum (c) final evaluation of 2013 curriculum's achievements, and (d) opposing and supporting factors in learning implementation of 2013 curriculum at Serayu elementary school. The involved participants were: principal, vice principal of curriculum,teachers, students, and student's parents. Data were collected through observation, in depth interview, and documentation. The validity of data was evaluated by persevering observation, data triangulation, and data checking. Data were evaluated continuously from the beginning. The procces of data collection consisted of three steps which were data reduction, data presentation, and drawing conclusion. This study reveals 4 things. First, lesson plans which are developed by teachers have been arranged in great detail according to certain themes and sub themes of 2013 curriculum's syllabus. Second, learning implementation conducted by teachers were opening, main activity and closing. Third, teachers evaluate learning achievements using evalution of attitude, cognitive and motoric. The process of evaluation was tests and non test, written and oral examination, performance observation, attitude measurement, task evaluation, portofolio uses, and self evaluation. Fourth, the difficulty in conducting 2013 curriculum were: huge amount of matter not supported by time allocation, evaluation exhausted the teachers.
\end{abstract}

Keywords: 2013 curriculum, learning implementation 


\section{Pendahuluan}

Kurikulum seringkali menjadi sesuatu yang kontroversial ketika terjadi perubahan. Jika ditelisik dari perjalanannya, perubahan kurikulum di Indonesia telah terjadi berkali-kali, respon pro-kontra pun berdatangan dari berbagai kalangan. Muncul pandangan di tengah masyarakat, bahwa setiap terjadi pergantian menteri maka kurikulum akan berganti pula. Hal ini senada dengan pendapat Tilaar \& Nugroho (2008, p. 5) bahwa pendidikan telah menjadi motor dari perubahan global yang radikal. Tidak mengherankan apabila pendidikan jadi rebutan kekuasaan dalam masyarakat. Partai-partai politik menjadikan pendidikan sebagai program yang utama atau sebagai iming-iming utama untuk membujuk rakyat di dalam pemilihan umum atau sebagai sarana untuk melestarikan kekuasaan atau jabatan.

Berkaitan dengan pendapat tersebut, maka tentu menjadi ironi bagi dunia pendidikan. Perubahan kebijakan khususnya pada bidang kurikulum tentu harus mengacu pada kepentingan bangsa dan negara dalam menjawab tantangan zaman. Pada hakikatnya, perubahan kurikulum merupakan upaya untuk memperbaiki dan menyempurnakan kurikulum sebelumnya. Perubahan yang terjadi adalah bentuk respon dari perubahan zaman, kondisi sosial-budaya masyarakat, maupun perkembangan teknologi informasi yang semakin pesat dan cepat. Perubahan kurikulum yang terkini adalah dari KTSP (Kurikulum Tingkat Satuan Pendidikan) ke Kurikulum 2013. Dalam proses pelaksanaannya Kurikulum 2013 ini dianggap kurang memiliki perencanaan yang matang dan tergesa-gesa, sehingga pada tahun 2015 pemerintah melalui Kementerian Pendidikan dan Kebudayaan (Kemendikbud) mengintruksikan kepada sekolah-sekolah yang belum siap, agar kembali menggunakan KTSP, sedangkan bagi sekolah yang kualitas SDM-nya bagus, fasilitas pembelajarannya baik dan telah menjalankan Kurikulum 2013 lebih dari 3 semester tetap melanjutkan implementasi Kurikulum 2013.
Inti dari pengembangan Kurikulum 2013 adalah pada upaya penyederhanaan, dan tematik-integratif. Selain itu, Kurikulum 2013 disiapkan untuk mencetak generasi yang siap di menghadapi masa depan. Karena itu kurikulum disusun untuk mengantisipasi perkembangan masa depan. Titik beratnya, bertujuan untuk mendorong peserta didik atau siswa dalam proses pembelajaran layaknya seorang peneliti atau penemu. Mereka belajar ibaratnya seorang ahli sains, sehingga proses-proses saintifik diterapkan kepada mereka seperti; pengamatan, bertanya, menggali informasi, dan mengkomunikasikan (mempresentasikan) apa yang mereka peroleh atau mereka ketahui dari apa yang mereka pelajari.

Melalui pendekatan itu diharapkan siswa memiliki kompetensi sikap, keterampilan, dan pengetahuan jauh lebih baik. Dengan pendekatan tersebut mereka diharapkan akan lebih kreatif, inovatif, dan lebih produktif, sehingga nantinya mereka dapat sukses dalam menghadapi berbagai persoalan dan tantangan di zamannya serta memasuki masa depan yang lebih baik (Kemendikbud, 2013).

Selain perubahan pada desain dan pendekatan pembelajaran, standar penilaian pun juga berubah. Standar Penilaian Pendidikan Kurikulum 2013 mengacu pada Permendikbud Nomor 66 tahun 2013 tentang standar penilaian pendidikan (Mendikbud RI, 2013) yakni kriteria mengenai mekanisme, prosedur, dan instrumen penilaian hasil belajar peserta didik. Penilaian pendidikan sebagai proses pengumpulan dan pengolahan informasi untuk mengukur pencapaian hasil belajar peserta didik mencakup: penilaian otentik, penilaian diri, penilaian berbasis portofolio, ulangan, ulangan harian, ulangan tengah semester, ulangan akhir semester, ujian tingkat kompetensi, ujian mutu tingkat kompetensi, ujian nasional, dan ujian sekolah/madrasah.

Jika pada kurikulum KTSP, penilaian lebih ditekankan pada aspek kognitif yang menjadikan tes sebagai cara penilai yang dominan, maka Kurikulum 2013 menekankan aspek kognitif, afektif, psikomo- 
torik secara proporsional yang sistem penilaiannya berdasarkan test, penilaian diri, penilaian sejawat, dan portofolio yang saling melengkapi. Sehingga kedepannya tidak lagi ada doktrin peserta didik yang bodoh atau kurang. Bisa jadi dalam hal akademik mereka kurang menonjol, barang tentu dalam hal sikap dan keterampilan lebih dominan daripada akademiknya.

Mengingat banyaknya perubahan dan penyempurnaan Kurikulum 2013, tentunnya implementasi Kurikulum 2013 menjadi tidak mudah. Apalagi setiap perubahan dan implementasi kurikulum baru selalu berkaitan dengan berbagai komponen pendidikan seperti; guru, kepala sekolah, sarana dan prasarana, dan berbagai perangkat pendidikan lainnya. Jika diantara beberapa komponen tersebut tidak mendukung atau tidak siap untuk dilakukan perubahan kurikulum, maka barang tentu implementasi kurikulum baru tidak akan berjalan dengan baik dan sesuai harapan.

Begitupun juga dengan Kurikulum 2013, salah satu pasang surut implementasi Kurikulum 2013 karena faktor kesiapan guru. Meskipun pemerintah telah mengupayakan pelatihan dan pendampingan untuk kepala sekolah dan guru-guru di seluruh Indonesia, nyatanya guru-guru masih banyak yang belum siap, sehingga banyak sekolah yang senang ketika diminta kembali menggunakan KTSP. Berbagai kekurangan dan keterbatasan mengenai pemahaman terhadap Kurikulum 2013 merupakan tantangan seorang teknolog pembelajaran.

Merujuk pada definisi teknologi pendidikan yang dikeluarkan AECT tahun 2004 (Prawiradilaga, 2012, p. 31) mengemukakan bahwa "educational technology is study and ethical practice of facilitating learning and improving performance by creating, using, and managing appropriate technological processes and resourcess". Berdasarkan definsi tersebut, maka posisi teknolog pendidikan pada pelaksanaan pembelajaran $\mathrm{Ku}-$ rikulum 2013 terdapat pada study and ethical practice, yang memungkinkan seorang teknolog pembelajaran untuk melakukan kajian terhadap Kurikulum 2013 dan melihat sejauh mana praktiknya di lapangan. Setelah itu teknolog pembelajaran dapat melakukan rumusan kritis dan solusi mengenai pelaksanaan Kurikulum 2013 yang ditinjau dengan proses creating, managing, using. Selain itu faktor-faktor yang mendukung keterlaksanaan Kurikulum 2013 dapat dilihat melalui telaah processes dan resources dalam berlangsung proses pembelajaran.

Berdasarkan hal tersebut, maka perlu dilakukan penelitian mengenai pelaksanaan pembelajaran menggunakan Kurikulum 2013 di tingkat yang mendasar. Melalui proses observasi, maka ditemukan sekolah dasar di Yogyakarta, yang melaksanakan Kurikulum 2013 secara bertahap yaitu SD Negeri Serayu Yogyakarta. SD Negeri Serayu Yogyakarta merupakan salah satu dari 15 SD yang melaksanakan $\mathrm{Ku}-$ rikulum 2013 di kota Yogyakarta, Daerah Istimewa Yogyakarta. Ada beberapa alasan penunjukan dan pemilihan SD Negeri Serayu Yogyakarta menjadi salah satu pilot project Kurikulum 2013 antara lain; sekolah ini merupakan sekolah dasar yang menempati ranking empat di kota Yogyakarta, peringkat sekolah ke-enam se-DIY, dan peringkat ke-2 pada tingkat UPT. Selain itu dua anak masuk ke provinsi peringkat enam besar dan 14 dari puluhan ribu siswa. (Wawancara dengan Kepala Sekolah, Sabtu 19 Desember 2015).

Faktor pendukung yang menjadikan SD Negeri Serayu Yogyakarta menjadi lokasi yang tepat untuk melakukan penelitian adalah karena prestasi dan beberapa faktor pendukung lainnya. Diantara prestasi yang telah diraih oleh SD Negeri Serayu Yogyakarta antara lain, peringkat dua (2) se DIY dalam ujian Sekolah, menjuarai berbagai ajang lomba cerdas cermat, dan lomba sains. Selain itu, SD Negeri Serayu Yogyakarta mendapatkan dukungan yang baik dari wali murid. Salah satu contoh dukungan kongkritnya ialah keberadaan LCD Proyektor di setiap ruang kelas siswa yang merupakan hasil iuran dan sumbangan sukarela dari wali murid sebagai bentuk dukungan kepada sekolah. Tidak hanya 
berhenti dalam dukungan fasilitas, mereka para wali murid juga memberikan dukungan moral dengan aktif ikut memantau kegiatan di sekolah, apabila terdapat hal yang perlu diperbaiki mereka tidak sungkan-sungkan memberikan kritik dan masukan bagi pihak sekolah.

Pertanyaan yang muncul adalah mengapa SD Negeri Serayu Yogyakarta melaksanakan Kurikulum 2013? bagaimana pelaksanaannya? Berdasarkan pertanyaanpertanyaan tersebut, maka dilakukan observasi dan wawancara untuk mendapatkan data-data awal. Hasilnya, terdapat beberapa masalah yang dirasakan oleh guru-guru SD Negeri Serayu Yogyakarta. Kurikulum 2013 memiliki dampak terhadap proses belajar mengajar baik dari aspek perencanaan, pelaksanaan, dan penilaian hasil belajar. Berikut hasil pra penelitian yang diperoleh dari pengamatan dan wawancara.

Pertama, Guru menganggap waktu yang dialokasikan dalam Kurikulum 2013 dianggap kurang. Kedua, terkait materi pembelajaran, materi pembelajaran dalam Kurikulum 2013 dianggap terlalu sedikit. Ketiga, permasalahan dalam Kurikulum 2013 yang dirasa menyulitkan adalah terkait penilaian. Guru menganggap penilaian dalam Kurikulum 2013 terlalu memberatkan. Keempat, persoalan lain yang muncul adalah salah persepsi antara isi pembelajaran dengan cara penyajiannya. Pembelajaran yang disajikan melalui permainan atau game hanya dipahami sebatas permainannya saja, sementara substansi dari pembelajaran yang disajikan melaui permainan-permainan tersebut belum dipahami secara utuh.

Kurikulum 2013 memang memiliki berbagai kekurangan, namun guru di SD Negeri Serayu Yogyakarta juga berkeyakinan akan mampu memperbaiki proses pembelajaran di kelas.

Berdasarkan dari hasil pra-penelitian tersebut, maka sangat menarik jika pelaksanaan pembelajaran Kurikulum 2013 ini dikaji lebih mendalam dan lebih komprehensif. Untuk itulah, dalam penyusunan tesis ini penulis mengambil tema "Pe- laksanaan Pembelajaran Kurikulum 2013 di SD Ne-geri Serayu Yogyakarta". Pemilihan tema ini untuk mengungkap lebih mendalam proses pembelajaran kurikulum 2013 di tingkat sekolah dasar (SD). Mengingat selama proses pembelajaran masih bersifat terpusat pada guru dan pengakuan keberhasilan belajar siswa diukur dari kemampuan kognitifnya, sedangkan hal-hal yang mengenai kompetensi sikap dan keterampilan selalu dikesampingkan. Jika Kurikulum 2013 dipahami dengan baik gagasannya oleh guru, serta mampu diterapkan dengan baik di sekolah khususnya SD sebagai peletak pondasi dasar, maka proses pembelajaran yang tercipta di ruang-ruang kelas maupun di lingkungan sekitar akan menjadi efektif, bermakna, dan menyenangkan.

Sesuai dengan uraian yang telah dikemukakan, maka penelitian ini bertujuaan untuk: (1) memperoleh informasi tentang proses pembelajaran pada Kurikulum 2013 yang terjadi di SDN Serayu Yogyakarta mulai dari sisi perencanaan, pelaksanaan, dan penilaian hasil belajar siswa; (2) memperoleh informasi tentang kendala dan hambatan yang terjadi dalam melaksanakan pembelajaran menggunakan Kurikulum 2013 di SDN Serayu Yogyakarta.

\section{Metode}

Penelitian ini menggunakan pendekatan kualitatif, sedangkan jenis penelitian yang tepat untuk menggambarkan temuan-temuan dalam penelitian ini adalah menggunakan jenis penelitian kualitatif deskriptif. Data hasil penelitian dianalisis dengan pendekatan kualitatif, disajikan secara deskriptif naratif. Analisis data dilakukan secara kontinyu setiap mendapatkan data mulai dari awal pengumpulan sampai akhir pengumpulan data. Pengumpulan data dalam penelitian diperoleh melalui observasi baik secara partisipan maupun nonpartisipan, analisis dokumen, dan wawancara secara mendalam.

Penelitian ini dilaksanakan di SD Negeri Serayu Yogyakarta. Sedangkan waktu penelitian dilaksanakan mulai bulan Mei 
sampai dengan Juni 2015 (untuk prasurvei) dan dari bulan Juli sampai dengan Desember 2015 (penelitian). Subjek penelitian dalam penelitian ini adalah seluruh komponen yang berkaitan dengan pelaksanaan pembelajaran Kurikulum 2013 di SD Negeri Serayu Yogyakarta antara lain: kepala sekolah, wakil kepala sekolah bidang kurikulum, dan guru kelas yang kesemuanya berjumlah enam orang, siswa yang sejumlah 12 orang yang terdiri dari masing-masing dua orang tiap kelas dari kelas satu sampai kelas enam dan yang terakhir adalah orang tua siswa. Objek penelitian ini adalah pelaksanaan pembelajaran Kurikulum 2013 di SD Negeri Serayu Yogyakarta. Pelaksanaan pembelajaran yang dijadikan objek adalah kegiatan perencanaan, pelaksanaan, dan penilaian hasil belajar siswa yang merupakan satu kesatuan. Kemudian mengenai faktor pendukung terhadap proses pembelajaran dan faktor penghambat yang menjadi kendala dalam pelaksanaan pembelajaran juga bagian dari penelitian ini.

Dalam suatu penelitian diperlukan adanya suatu data sebagai hasil akhir dari penelitian. Data dikumpulkan menggunakan teknik dan instrumen sebagai berikut:

Pertama, penelitian ini menggunakan teknik pengumpulan data observasi partisipasi pasif dalam pembelajaran, namun tidak ikut terlibat di dalamnya. Observasi yang dilakukan pada saat proses pembelajaran berlangsung meliputi kegiatan pendahuluan, kegiatan inti, dan kegiatan penutup. Observasi juga dilakukan terhadap teknik penilaian yang digunakan oleh guru, serta kemungkinan hambatan dan upaya yang dilakukan oleh guru untuk mengatasi hambatan yang ditemui saat proses pembelajaran berlangsung.

Dalam penelitian ini juga dilakukan observasi terhadap guru mengenai perencanaan pembelajaran, pelaksanaan pembelajaran, dan penilaian hasil belajar siswa serta dilengkapi dengan pedoman observasi kegiatan siswa dalam pembelajaran.

Kedua, selain menggunakan observasi, penelitian ini juga menggunakan teknik wawancara. Teknik wawancara yang digunakan dalam penelitian ini menggunakan wawancara semi terstruktur. Jenis wawancara ini tergolong dalam kategori indept interview, yaitu dalam pelaksanaannya lebih bebas bila dibandingkan dengan wawancara terstruktur. Sebelum melakukan kegiatan wawancara, terlebih dahulu disusun pedoman wawancara dengan tujuan agar proses tetap terfokus dan tidak keluar dari konteks yang menjadi tujuan utama peneliti. Informan yang dipilih oleh peneliti dalam penelitian ini adalah kepala sekolah, waka kurikulum, guru, dan siswa.

Ketiga, studi dokumentasi. Studi dokumentasi digunakan untuk melengkapi penggunaan metode observasi dan wawancara dalam penelitian deskriptif. Studi dokumentasi dalam penelitian ini dilakukan untuk memperoleh data mengenai perencanaan pembelajaran, pelaksanaan pembelajaran, dan penilaian hasil belajar siswa. Dalam penelitian ini, peneliti mendokumentasikan kegiatan pembelajaran di kelas satu sampai dengan kelas enam. Kemudian juga, peneliti mengambil dokumen-dokumen yang berupa profil sekolah, rencana pelaksanaan pembelajaran (RPP), instrumen penilaian, dan lain-lain.

Pengujian keabsahan data dilakukan dengan cara ketekunan/keajegan pengamatan, trianggulasi data dan auditing atau pemeriksaan data. Berkaitan dengan hal tersebut, maka langkah-langkah yang ditempuh dalam pengujian keabsahan data sebagai berikut:

Pertama, ketekunan pengamatan bermaksud menemukan ciri-ciri dan unsur-unsur dalam situasi yang sangat releven dengan persoalan atau isu yang sedang dicari dan kemudian memusatkan diri pada hal-hal tersebut secara rinci. Keajegan pengamatan diupayakan mencari secara konsisten interpretasi dengan berbagai cara dalam kaitan dengan proses analisis yang konstan dan tentatif, dengan cara mencari konsistensi apa yang dapat diperhitungkan dengan apa yang tidak dapat, agar data betul-betul valid, akurat, dan bisa dipertanggungjawabkan 
Kedua, triangulasi data, yaitu memeriksa keabsahan data melaui sumber, teknik dan teori. Triangulasi sumber memungkinkan peneliti melakukan pengecekan ulang dan melengkapi informasi dengan sumber-sumber lain. Triangulasi sumber dalam penelitian ini dilakukan antara kepala sekolah, guru, dan siswa. Triangulasi teknik prosesnya dengan menguji kredibilitas data yang dilakukan dengan cara mengecek data kepada sumber yang sama namun dengan teknik yang berbeda. Data yang diperoleh dengan wawancara, kemudian dicek dengan data yang diperoleh dari observasi, dan dokumentasi. Triangulasi teknik yang digunakan oleh peneliti dalam penelitian ini adalah antara observasi, wawancara dan dokumentasi. Triangulasi dengan teori digunakan untuk mempertajam analisis penelitian dengan memeriksa derajat kepercayaan data

Dalam penelitian ini analisis data dilakukan secara terus-menerus sejak awal pengumpulan data. Pada prosesnya terdiri dari atas tiga tahapan yang saling terkait yaitu reduksi data, penyajian data, dan pengambilan kesimpulan. Proses analisis data dilakukan mulai proses awal hingga akhir pengumpulan.

Seluruh data yang telah dikumpulkan melalui wawancara secara mendalam, observasi baik secara partisipan maupun non partisipan, dan analisis dokumen direduksi dengan cara:

Pertama, menyeleksi, menentukan fokus, menyederhanakan dan mentransformasikan data yang muncul pada catatan lapangan. Reduksi data yang dilakukan berupa penulisan ringkasan, penajaman, pengkodean, pemfokusan, pembuangan, dan penyusunan data sehingga kesimpulan dapat ditarik, dibuktikan, dan dipertanggungjawabkan. Data yang diperoleh juga diklasifikasikan menjadi sub-sub. Klasifikasi dalam penelitian ini, terdiri dari; perencanaan pembelajaran, pelaksanaan pembelajaran, penilaian hasil belajar dengan menggunakan penilaian autentik, dan hambatan serta kendala yang dihadapi.
Kedua, melakukan analisis data baik pada perencanaan pembelajaran, pelaksanaan pembelajaran, penilaian hasil belajar, dan hambatan serta kendala dalam pelaksanaan pembelajaran. Data pelaksanaan pembelajaran dianalisis berdasarkan Permendikbud Nomor 65 Tahun 2013 Tentang Standar Proses Pendidikan Dasar dan Menengah dan berdasarkan teori yang ada (Mendikbud RI, 2013b). Setelah analisis data selesai, maka data disajikan dalam bentuk naratif yang mendeskripsikan perencanaan pembelajaran, pelaksanaan pembelajaran, penilaian hasil belajar, dan hambatan serta kendala dalam pelaksanaan. Kemudian dilakukan pembahasan terhadap deskripsi data. Pembahasan berusaha menemukan gambaran dan menginterpreasikan apa yang terkandung dalam perencanaan pembelajaran, pelaksanaan pembelajaran, evaluasi hasil belajar. Berdasarkan deskripsi data dan pembahasan, selanjutnya disimpulkan. Kesimpulan ini nantinya akan menjawab pertanya-pertanyaan yang ada pada rumusan masalah penelitian ini.

\section{Hasil dan Pembahasan}

\section{Hasil Penelitian}

Penelitian tentang pelaksanaan pembelajaran kurikulum 2013 di SD Negeri Serayu Yogyakarta ini meliputi perencanaan, pelaksanaan, penilaian, dan hambatan yang ditemui serta upaya yang dilakukan oleh guru untuk mengatasi persoalan tersebut. Data-data di bawah ini merupakan sekumpulan data yang diperoleh dari hasil pengamatan, observasi, wawancara dan telaah dokumen. Data-data di bawah ini tentunya sudah melalui berbagai rangkain kaidah penelitian seperti, ketekunan, keajegan pengamatan, trianggulasi data, dan auditing. Langkah-langkah tersebut kemudian dilanjutkan dengan analisis data dengan menyeleksi, menentukan fokus, menyederhanakan dan mentransformasikan data yang muncul pada catatan lapangan. Beberapa poin penting yang dianalisis ialah pada perencanaan pembelajaran, pelaksanaan pembelajaran, penilaian hasil 
belajar, dan hambatan serta kendala dalam pelaksanaan pembelajaran. Untuk itu, berikut hasil data-data pelaksanaan pembelajaran kurikulum 2013 di SD Negeri Serayu Yogyakarta.

\section{Perencanaan Pembelajaran}

Data-data yang diperoleh dalam perencanaan pembelajaran adalah sebagai berikut:

Pada tahap awal penerapan Kurikulum 2013, guru-guru mengalami kebingungan dan kesulitan. Hal ini dikarenakan guru-guru belum beradaptasi dan membutuhkan pelatihan-pelatihan (Kurikulum 2013) yang berkelanjutan. Sejak awal Kurikulum 2013 pertama diterapkan hingga penelitian ini dilakukan semua guru dan pimpinan sekolah terus belajar mengimplementasikan Kurikulum 2013 dengan baik dan sesuai dengan harapan pemerintah. Seperti biasa, layaknya sekolah yang baru menerapkan kurikulum baru memang ada kesulitan dan kebingungan. Di awal pelaksanaan Kurikulum 2013, kebingungan itu muncul saat mengembangkan RPP dan instrumen penilaian. Karena Kurikulum 2013 dari segi perangkat pembelajarannya lebih administratif daripada KTSP. Tapi untuk tahun kedua dan tahun ketiga ini karena telah sedikit banyak memiliki pengalaman dan pengetahuan menerapkan Kurikulum 2013, maka pada tahun-tahun itu pelaksanaan Kurikulum 2013 untuk SD Negeri Serayu Yogyakarta berjalan dengan baik. Jikalau ada perubahan bentuk instrumen penilaian dan RPP dari asesor, guru-guru tinggal menyesuaikan sesuai format yang baru.

Pada bagian awal pelaksanaan $\mathrm{Ku}-$ rikulum 2013, beberapa kesulitan penerapan Kurikulum 2013 di SD Negeri Serayu Yogyakarta mampu diminimalisir dengan adanya guru instruktur. Ditunjuknya beberapa guru sebagai instruktur nasional untuk mendampingi penyelenggaraan Kurikulum 2013 di sekolah turut membantu guru-guru di SD Negeri Serayu Yogyakarta. Setidaknya terdapat 3 orang guru yang ditunjuk oleh Kementerian Pendidikan dan Kebudayaan. Tugas instruktur nasional ini antara lain memberikan pendampingan terhadap guru-guru mulai dari perencanaan pembelajaran, pelaksanaan pembelajaran, dan evaluasi terhadap pencapaian kompetensi. Oleh karena itu, keberadaan instruktur nasional ini memberikan dampak yang positif terhadap guru-guru dalam penyusunan RPP.

Usaha lainnya yang dilakukan oleh Kepala Sekolah untuk memperkuat pemahaman terkait Kurikulum 2013 adalah dengan mengadakan rapat evaluasi dan KKG untuk seluruh guru di SD Negeri Serayu Yogyakarta. KKG ini dilakukan setiap bulan, sehingga jika terdapat guru-guru yang masih mengalami kesulitan dalam Kurikulum 2013, khususnya perencanaan pembelajaran (penyusunan RPP) dapat dikoordinasikan pada forum tersebut.

RPP yang dibuat oleh guru sangat dipengaruhi oleh forum KKG yang dipimpin oleh kepala sekolah. Forum tersebut sangat mempengaruhi penyusunan RPP di SD Negeri Serayu Yogyakarta. Berdasarkan telaah RPP tersebut, RPP yang disusun hampir mirip antara guru yang satu dengan guru yang lain. Untuk memperkuat data yang telah disusun, selanjutnya akan dideskripsikan data hasil observasi dan hasil wawancara antara guru, waka kurikulum, kepala sekolah, siswa, dan orang tua siswa.

Pada tahap perencanaan, guruguru di SD Negeri Serayu Yogyakarta pada umumnya melakukan kegiatan yang sama, namun ada beberapa pengembangan atau improvisasi dari masing-masing guru tersebut. Pengembangan RPP memang dianjurkan kepada guru-guru sepanjang tidak keluar dari jalur yang telah ditetapkan dalam Kurikulum 2013. Guru-guru di SD Negeri Serayu Yogyakarta mempersiapkan dan menyusun rencana pembelajaran dengan Rencana Pelaksanaan Pembelajaran (RPP).

Pelaksanaan Kurikulum 2013 pada sekolah dasar dilakukan melalui pembelajaran dengan pendekatan saintifik dan 
pendekatan tematik-integratif dari kelas I sampai kelas VI. Pembelajaran tematikintegratif merupakan pendekatan pembelajaran yang mengintegrasikan berbagai kompetensi dari berbagai mata pelajaran ke dalam berbagai tema.

Berkaitan dengan hal tersebut, sebagai bagian dari sekolah yang menerapkan kurikulum 2013, SD Negeri Serayu Yogyakarta tentunya juga menggunakan pendekatan tematik integratif dalam pembelajaran. Selain menggunakan pendekatan tematik-integratif, layaknya sekolah-sekolah yang menyelenggarakan Kurikulum 2013 pada khususnya, guru-guru SD Negeri Serayu Yogyakarta juga menggunakan pendekatan saintifik dalam pembelajaran.

\section{Pelaksanaan Pembelajaran}

Berdasarkan hasil pengamatan dari Oktober sampai dengan Desember 2015 memperlihatkan bahwa saat pembelajaran berlangsung, pembelajaran yang terjadi di ruang kelas pada umumnya berjalan dengan lancar. Interaksi antara guru dan siswa terlihat lebih intensif, walaupun ada beberapa siswa di masing-masing kelas yang kurang terlibat. Fasilitas untuk mendukung jalannya pembelajaran di SD Negeri Serayu Yogyakarta sangat baik. Beberapa fasilitas tersebut antara lain LCD Proyektor, Alatalat peraga, laptop/komputer, internet, ATK, buku guru dan siswa, media pembelajaran, ruang perpustakaan, lab komputer, dan fasilitas pendukung lainnya.

Berdasarkan hasil observasi di kelas I sampai dengan VI yang menjadi objek penelitian, ditemukan bahwa pelaksanaan pembelajaran terdiri dari kegiatan pendahuluan, kegiatan inti, dan kegiatan penutup. Berikut ini merupakan gambaran deskriptif mengenai pelaksanaan pembelajaran menggunakan Kurikulum 2013 di SD Negeri Serayu Yogyakarta.

Pendahuluan. Pertama, dalam kegiatan pendahuluan yang menjadi kegiatan pokok dan keharusan bagi guru ialah menyiapkan peserta didik secara psikis dan mental untuk mengikuti proses pembela- jaran. Dalam kegiatan ini guru memberikan setimulus yang dapat membantu siswa agar berada pada posisi siaga secara intelektual dan fisik. Kedua, memberi motivasi belajar peserta didik secara kontekstual. Pemberian motivasi tidak hanya dalam bentuk kata-kata verbal, tetapi juga dapat menghadirkan video pembelajaran yang dapat menggugah semangat siswa.

Ketiga, mengajukan pertanyaan-pertanyaan tentang materi yang sudah. Pengajuan pertanyaan dalam rangka mengetahui kesiapan siswa menerima materi yang baru. Keempat, mengantarkan peserta didik kepada suatu permasalahan atau tugas yang akan dilakukan untuk mempelajari suatu materi dan menjelaskan tujuan pembelajaran atau KD yang akan dicapai; dipelajari dan terkait dengan materi yang akan dipelajari.

Kelima, menyampaikan garis besar cakupan materi dan penjelasan tentang kegiatan yang akan dilakukan peserta didik untuk menyelesaikan permasalahan atau tugas. Keenam, menyampaikan aspek yang akan dinilai selama proses pembelajaran.

Kegiatan Inti. Berdasarkan hasil pengamatan yang intensif di kelas-kelas yang menjadi obyek penelitian, diperoleh data bahwa kegiatan inti yang dilakukan guru-guru di SD Negeri Serayu Yogyakarta menonjolkan kegiatan 5M. Hal tersebut merupakan bentuk implementasi Kurikulum 2013 yang diselenggarakan secara menyeluruh $100 \%$ di SD Negeri Serayu Yogyakarta. Kegiatan 5M dalam Kurikulum 2013 meliputi kegiatan mengamati, menanya, mengumpulkan informasi/mencoba, mengasosiasi/menalar, dan mengkomunikasikan. Kegiatan 5M tersebut tidak semua dilaksanakan setiap pertemuannya, hal tersebut dikarenakan minimnya waktu.

Alokasi waktu yang tersedia belum cukup mengakomodir jumlah waktu pelaksanaan pendekatan saintifik. Persoalan ini boleh jadi karena guru kurang kreatif dalam melaksanakan atau memang pendekatan saintifik jika dilaksanakan secara sintak membutuhkan waktu yang cukup lama. Akan tetapi di sini peneliti tidak mau 
terjebak pada persoalan tersebut. Karena untuk memperoleh jawaban komprehensif dibutuhkan waktu khusus dan fokus mengkaji pendekatan saintifik. Dalam hal ini peneliti sengaja tidak banyak mengupas tentang persoalan waktu tersebut, karena penelitian ini diarahkan untuk memotret pelaksanaan kurikulum 2013 di SD Negeri Serayu Yogyakarta.

Untuk itu, terlepas dari persoalan waktu, kreativitas guru memang sangat diperlukan dalam melaksankan Kurikulum 2013. Guru yang tidak kreatif akan menjadikan Kurikulum 2013 terasa memberatkan. Kegiatan 5M yang menjadi ciri khas utama Kurikulum 2013 bukan untuk memberatkan guru, namun kegiatan tersebut diperuntukkan kepada siswa agar terlaksana pembelajaran yang aktif.

Kegiatan Penutup. Hasil observasi yang dilakukan di masing-masing kelas memperlihatkan bahwa pada kegiatan penutup dilakukan dengan beberapa aktivitas seperti menyimpulkan tema pembelajaran, melaksanakan refleksi, adanya feedback, penilaian, menyampaikan informasi pembelajaran pada pertemuan selanjutnya, pemberian pekerjaan rumah, dan do'a penutup.

\section{Penilaian Hasil Belajar}

Guru-guru di SD Negeri Serayu Yogyakarta melakukan penilaian pembelajaran dengan menyesuaikan 3 aspek dalam penilaian Kurikulum 2013 yaitu penilaian sikap, pengetahuan, dan keterampilan. Berikut ini adalah penjabaran dari masingmasing penilaian yang terdapat dalam penilaian yang terdiri penilaian sikap, pengetahuan, dan keterampilan.

Penilaian Sikap

Berdasarkan hasil observasi, guruguru di SD Negeri Serayu Yogyakarta melakukan penilaian sikap melaui pengamatan pada saat proses belajar mengajar berlangsung. Siswa yang menonjol pada saat berlangsungnya pembelajaran akan mendapat reward lebih dari guru. Sementara siswa yang tidak aktif terlebih nakal akan mendapat catatan khusus dari guru. Sebagai contoh guru kelas IIA, guru Fz memberikan reward berupa "bintang" kepada siswa yang bersikap baik, berani, dan cerdas.

Guru kelas VC bahkan menilai sikap lebih detail lagi, HN telah menyiapkan instrumen untuk aktivitas siswa selama proses pembelajaran berlangsung. Selain itu, HN juga menerima laporan-laporan baik dari sesama guru ataupun karyawan sekolah terkait siswa-siswinya.

Selain menggunakan lembar pengamatan, untuk menilai kompetensi sikap guru juga menggunakan penilaian sejawat. Dalam artian, guru meminta masukan dan catatan antar-teman. Dari hasil pengamatan di lapangan menunjukkan sesekali pernah guru meminta siswa untuk menulis catatan yang berisikan sikap teman sebelahnya.

Penilaian sejawat digunakan sebagai perbandingan dari hasil pengamatan yang telah dilakukan guru. Selain itu juga untuk mengetahui tingkat kejujuran dan keberanian siswa dalam mengungkapkan kebaikan dan kekurangan pada temantemannya.

Kemudian instrumen yang digunakan untuk menilai kompetensi sikap, guru juga menggunakan jurnal. Dari hasil pengamatan, penggunaan jurnal bersifat internal. Dalam artian siswa sendiri yang mengisi instrumen penilaian dan kemudian guru yang menentukan bobot nilainya di akhir semester. Pada konteks ini guru melihat dan menelaah isi jurnal yang berisikan catatan siswa mengenai kegiatankegiatan positif yang dilakukan baik di lingkungan sekolah maupun di rumah dan di tengah-tengah masyarakat. Selain siswa mengisi sendiri, jurnal juga berisi catatan orangtua terkait kegiatan anak selama di rumah.

\section{Penilaian Pengetahuan}

Berdasarkan hasil observasi, guru menggunakan instrumen yang telah disiapkan berdasarkan ketentuan pada Kurikulum 2013. Hasil yang ditemukan di lapangan membuktikan bahwa guru-guru di 
SD N Serayu Yogyakarta menggunakan instrumen tes tertulis untuk menilai pengetahuan siswa. Instrumen tertulis yang digunakan guru antara lain jawaban singkat, soal isian, dan uraian. Adapun soal isian dan jawaban singkat tersebut berasal dari buku siswa dan buku sumber yang lain.

Soal-soal untuk mengetahui pengetahuan siswa sebagian besar diambil dari buku yang dimiliki oleh siswa. Hal tersebut dikarenakan kesesuaian buku dengan Kurikulum 2013. Selain itu, guru juga menggunakan instrumen penugasan individu maupun kelompok yang bisa dikerjakan pada saat proses pembelajaran berlangsung maupun menjadi pekerjaan rumah (PR).

Pemberian soal untuk menilai pengetahuan siswa dilakukan pada beberapa tahapan, pada saat sub-tema dan tema selesai, ujian tengah semester, dan ujian akhir semester. Siswa yang masih kurang dari KKM yang telah ditetapkan akan mendapatkan remidi.

Dari hasil pengamatan di lapangan, penilaian kompetensi pengetahuan selain menggunakan tes tertulis sebagaimana diungkapkan di atas, guru juga lebih sering menggunakan tes lisan. Tes secara lisan digunakan ketika guru akan menutup kegiatan pembelajaran. Bentuk kegiatan tes lisan ini dari hasil pengamatan lebih banyak pada kuis-kuis kompetitif. Guru mengarahkan siswa agar berkompetisi menjawab soal-soal yang dikemukakan oleh guru. Siswa yang berhasil memcahkan soal, mereka mendapatkan poin yang diakumulasikan pada akhir semester dan dikonvrensi menjadi nilai.

Penilaian Keterampilan

Hasil pengamatan selama observasi menunjukkan bahwa guru menggunakan penilaian kinerja dan penilaian proyek untuk menilai keterampilan yang dimiliki oleh siswa. Guru menilai bagaimana siswa menggambar, bernyanyi, membuat pertanyaan, membacakan puisi, bagaimana siswa karya, dan lain sebagainya. Pemberian penilaian keterampilan siswa dilakukan dengan kreativitas guru di masing-masing kelas. Pemberian penilaian dapat langsung disampaikan oleh guru, tertutup, dan ada juga yang memberikan penilaian dengan memberikan icon bintang untuk siswa. Hal tersebut sesuai dengan hasil pengamatan di kelas IIA. Guru Kelas IIA memberikan icon bintang kepada siswa yang tampil kreatif dalam bernyanyi, bintang tersebut kemudian di tempel oleh siswa yang mendapatkannya di papan penilaian kreatifitas yang telah disiapkan di dalam kelas.

Penilaian keterampilan yang dilakukan oleh guru kelas IIA tersebut membuat siswa termotivasi untuk belajar, berani berkasi dan mempersiapkan diri masingmasing untuk tampil bernyanyi di depan teman-temannya. Selain memberikan penghargaan kepada siswa yang terampil, guru juga memberikan icon petir untuk siswa yang tidak berkelakuan baik. Icon petir tersebut dapat mengurangi icon bintang yang telah diperoleh oleh siswa tersebut. Selain melihat dari kemampuan siswa bernyanyi dan berpuisi, guru juga menilai kompetensi keterampilan siswa dari kemampuan dalam mempresentasikan atau mengkomunikasikan hasil tugas. Ada banyak hal yang dinilai dari kegiatan siswa mengkomunikasikan tugasnya. Dari mulai cara menyampaikan (lisan maupun perbuatan) hingga bentuk tugas yang disampaikan. Bentuk tugas yang dimaksud ialah keindahan, kerapian, dan ketepan tugas yang dihasilkan.

\section{Hambatan-Hambatan}

\section{Perencanaan Pembelajaran}

Hambatan yang dialami oleh guru dalam perencanaan pembelajaran antara lain adalah pembuatan RPP. Guru merasakan kesulitan dalam menentukan langkah pembelajaran saintifik dan instrumen penilaiaannya. Selain itu, kendala lainnya adalah menentukan waktu, sering kali perencanaan yang telah direncanakan di dalam RPP tidak terlaksana pada saat berlangsungnya pembelajaran. Guru mengeluhkan masalah waktu berulang kali. 


\section{Pelaksanaan Pembelajaran}

Hambatan yang dialami oleh guruguru di SD N Serayu Yogyakarta dalam pelaksanaan pembelajaran adalah karena ketidaksiapan siswa dalam melaksanakan Kurikulum 2013. Hal ini dikarenakan oleh penerapan Kurikulum 2013 yang masih baru, siswa belum terbiasa. Sehingga terjadi kurang percaya diri dalam diri siswa.

Hambatan lainnya, berdasarkan hasil observasi di kelas-kelas, hambatan dalam pelaksanaan pembelajaran justru dari faktor guru. Guru masih menggunakan strategi pembelajaran yang sama dan berulang-ulang dalam menyampaikan materi pembelajaran. Variasi strategi pembelajaran sangat diperlukan sehingga kurikuLum 2013 dapat terlaksana dengan efektif, efisien, dan menyenangkan.

\section{Penilaian Hasil Belajar}

Hambatan yang dialami guru dalam penilaian pembelajaran yaitu banyaknya aspek yang harus dinilai dalam penilaian Kurikulum 2013. Oleh karena itu, guru memerlukan waktu yang lama untuk melakukan koreksi dan penialaian. Hampir rata-rata guru di SD N Serayu Yogyakarta mengeluhkan hal yang sama.

Pembahasan

Berdasarkan uraian data yang telah dipaparkan di atas, maka berikut akan dilakukan analisis data berdasarkan faktafakta yang ditemukan dalam pelaksanaan pembelajaran menggunakan Kurikulum 2013. Analisis terhadap pelaksanaan pembelajaran dimulai dari perencanaan, pelaksanaan, dan penilaian hasil belajar.

Perencanaan Pembelajaran

Tahap pertama dalam pembelajaran adalah perencanaan pembelajaran yang diwujudkan dengan kegiatan penyusunan rencana pelaksanaan pembelajaran atau RPP. Hasil penelitian menunjukkan bahwa guru telah membuat RPP untuk satu semester, bahkan ditemukan RPP untuk satu tahun ajaran. Sehingga guru tidak membuat RPP per-pertemuan atau per-tema.
Kajian silabus yang dilakukan guru meliputi pencermatan KI dan KD yang terdapat dalam silabus. Berdasarkan hasil telaah terhadap dokumen RPP yang telah dibuat oleh guru-guru di SD Negeri Serayu Yogyakarta menunjukkan bahwa komponen-komponen RPP tematik tersebut telah sesuai dengan komponen-komponen RPP berdasarkan ketentuan Kurikulum 2013. Hal tersebut dikarenakan penyuluhan dan pelatihan yang guru ikuti sebelum menerapkan Kurikulum 2013.

Selain itu, hasil analisis RPP menunjukkan bahwa guru sudah menjabarkan pendekatan saintifik pada RPP yang disusun, namun dalam menjabarkan pendekatan saintifik tersebut, guru masih mengacu pada buku guru. Sehingga terjadi kekakuan dalam pelaksanaannya, guru seharusnya mengembangkannya sesuai dengan situasi dan kondisi siswa beserta lingkungan sekolahnya. Sebagaimana dijelaskan dalam ketentuan dalam Kurikulum 2013 bahwa penjabaran kegiatan pembelajaran yang ada pada silabus dalam bentuk yang lebih operasional berupa pendekatan saintifik disesuaikan dengan kondisi siswa dan satuan pendidikan termasuk penggunaan media, alat, bahan, dan sumber belajar.

Guru-guru di SD Negeri Serayu Yogyakarta menjabarkan pendekatan saintifik dalam RPP yang meliputi mengamati, menanya, mengumpulkan informasi/mencoba, mengasosiasi/menalar, dan mengkomunikasikan $(5 \mathrm{~m})$. Penulisan kegiatan 5M dalam RPP tidaklah urut. Hasil analisis RPP mengenai instrumen penilaian yang terdiri dari aspek sikap, pengetahuan, dan keterampilan belum dilengkapi dengan rubrik penilaian. Selain itu, penilaian tes tertulis dan observasi tidak disertai dengan soal-soal dan hal-hal yang akan diobservasi.

Temuan lain selama penelitian adalah tentang waktu. Bahkan persoalan waktu menjadi keluhan utama guru dalam Kurikulum 2013. Berdasarkan hasil penelitan, terdapat kegiatan pembelajaran yang belum tersampaikan karena alokasi waktu yang tidak mencukupi. Oleh karena itu, guru-guru di SD Negeri Serayu Yogyakarta 
menyiasatinya dengan melakukan tambahan waktu untuk memenuhi materi pembelajaran yang belum tersampaikan.

Secara keseluruhan, pada tahap kegiatan perencanaan pembelajaran menggunakan Kurikulum 2013, guru-guru di SD Negeri Serayu Yogyakarta tidak mengalami kendala berarti. Hal tersebut dapat dibuktikan dengan hasil telaah RPP dan hasil wawancara dengan guru-guru yang telah dipaparkan sebelumnya. Maka dari itu, pada tahap perencanaan kegiatan pembelajaran Kurikulum 2013 guru-guru telah menguasai dengan baik segala proses penyusunannya.

\section{Pelaksanaan Pembelajaran}

Berdasarkan hasil penelitian, pelaksanaan pembelajaran yang dilakukan oleh guru-guru di SDN Serayu Yogyakarta adalah dengan menggunakan pendekatan saintifik dan pendekatan tematik-integratif yang terdiri dari kegiatan pendahuluan, kegiatan inti, dan kegiatan penutup.

\section{Kegiatan Pendahuluan}

Kegiatan pendahuluan yang dilakukan guru antara lain mengkondisikan kelas, berdoa, mengecek siswa/membacakan presensi, menyampaikan kompetensi yang akan dicapai siswa, apersepsi, dan membacakan tujuan pembelajaran. Pada praktiknya, guru rutin mendiskusikan kompetensi dan melakukan tanya jawab terkait materi pembelajaran yang telah dipelajari. Hal tersebut sangat memang sangat diperlukan untuk mengukur pemahaman siswa-siswa terkait sub-tema/tema yang telah dipelajari.

Salah satu kendala yang ditemukan yakni guru-guru terlihat jarang menyampaikan kompetensi yang akan dicapai beserta manfaatnya dalam kehidupan sehari-hari. Padahal hal tersebut sangat diperlukan agar siswa mampu memahami dan menyelesaikan masalah dalam dunia nyata. Siswa perlu mengetahui manfaat pembelajaran dalam kehidupan sehari-hari sehingga mereka (siswa) mampu menga- itkannya dalam kehidupan sosialnya. Namun hal tersebut, tidak berarti guru tidak menyampaikan pesan-pesan mengenai kaitan pembelajaran dengan kehidupan nyata. Hal tersebut dilakukan secara tidak langsung dalam kegiatan inti pada proses berlangsungnya pembelajaran maupun pada saat di luar proses pembelajaran.

\section{Kegiatan Inti}

Kegiatan inti dalam pembelajaran yang dilakukan guru adalah menggunakan pendekatan saintifik yang meliputi kegiatan $5 \mathrm{M}$. Berdasarkan hasil penelitian, kegiatan 5M tersebut mengacu pada ketentuan dalam Kurikulum 2013. Pelaksanaan 5M tersebut tidaklah berurutan, bahkan dalam satu pertemuan tidak tercakup semua.

Kegiatan mengamati yang dilakukan oleh siswa antara lain mengamati gambar dalam buku LKS masing-masing siswa, mengamati alat bantu berupa kubus, mengamati video pembelajaran dan multimedia pembelajaran, dan lain-lainnya. Kegiatan mengamati ini dipantau oleh guru. Siswa yang terlihat tidak mengamati akan mendapat teguran dan akan ditanya oleh guru.

Kegiatan yang seringkali dilakukan oleh guru adalah melakukan kegiatan 'menanya'. Terlebih setelah kegiatan mengamati. Guru memberikan kesempatan antara siswa untuk saling menanya mengenai temuan yang didapatkan oleh siswa setelah melakukan pengamatan. Siswa terlihat masih belum terlalu aktif untuk bertanya, siswa masih malu dan tidak berani bertanya dan menyampaikan pendapatnya. Hal tersebut dibantu oleh guru agar siswa berani, guru melatih mereka untuk tidak takut. Guru mengajarkan siswa untuk membuat kalimat tanya. Hal ini dilakukan karena siswa-siswa masih membutuhkan pendampingan agar berani dan tidak malu..

Berdasarkan hasil penelitian, kegiatan mengumpulkan informasi/mencoba dilakukan dengan berdiskusi. Namun kegiatan mengumpulkan informasi/mencoba masih jarang dilakukan. Seharusnya kegiatan mengumpulkan informasi melibatkan 
narasumber atau lingkungan sekitarnya. Siswa bisa melakukan kegiatan mengumpulkan informasi baik melalui bertanya maupun wawancara dengan berbagai sumber maupun narasumber.

Kendala yang dihadapi guru adalah waktu. Sehingga kegiatan ini difokuskan hanya di ruang kelas dengan melakukan kegiatan diskusi. Oleh karena itu, siswa dapat melakukan pengumpulan informasi dari masing-masing kelompok. Kegiatan diskusi dilakukan dengan cara berkelompok. Guru membagi siswa berdasarkan nomor urut absen atau disesuaikan dengan tempat duduk.

Berdasarkan hasil penelitian, kegiatan menalar yang dilakukan di SD Negeri Serayu Yogyakarta antara lain dengan mengaitkan informasi (mata pelajaran) menjadi informasi yang utuh. Siswa diberikan kesempatan untuk bereksperimen dengan ilmu pengetahuan yang telah didapatkan. Selain itu, kegiatan menalar yang dilakukan adalah dengan mengerjakan soal. Seperti yang dilakukan di kelas VI, siswa diberikan kesempatan menalar dengan menjawab kuis, siswa-siswa pun terlihat semangat, ber-adu cepat dalam menjawab soal yang diberikan oleh guru.

Kegiatan mengasosiasi/menalar lainnya yang dilakukan guru adalah membimbing siswa melakukan tanya jawab untuk menyimpulkan hasil diskusi yang sudah dilakukan oleh siswa. Namun, saat bertanya jawab untuk menarik kesimpulan ada siswa yang kurang aktif mengikuti kegiatan tersebut. Hal ini dikarenakan guru melakukan tanya jawab secara klasikal. Sehingga beberapa siswa merasa kurang diperhatikan dan justru menjadi kurang aktif. Sebenarnya guru bisa memberikan giliran pertanyaan kepada siswa tersebut agar siswa merasa diperhatikan dan menjadi aktif dalam kegiatan pembelajaran.

Berdasarkan hasil penelitian, kegiatan mengkomunikasikan yang dilakukan oleh siswa adalah dengan membacakan hasil karya atau pekerjaannya baik perseorangan maupun kelompok. Siswa diminta maju perorangan maupun kelompok untuk mempresentasikan hasil karya/tugas yang telah dilakukan. Setelah itu guru memberikan kesempatan kepada siswa yang lain untuk memberikan tanggapan atau pertanyaan kepada siswa yang sedang mempresentasikan hasil karyanya.

Kegiatan mengkomunikasikan ini menuntut siswa untuk terlatih dalam menyampaikan ide, gagasan, dan informasi yang dimilikinya. Kegiatan mengkomunikasikan dapat mengembangkan kemampuan siswa menyampaikan pendapat dan menyentuh wilayah sosial skill dalam diri siswa. Selain itu, kepercayaan diri siswa akan meningkat dengan keberaniannya menampilkan tugas atau karya di depan teman-temannya.

Lima kegiatan yang disebutkan di atas, telah sesuai dengan hakikat pendekatan saintifik sebagaimana diutarakan oleh Fadlillah (2014, p. 175) yang mengatakan bahwa pendekatan saintifik adalah pendekatan pembelajaran yang dilakukan melalui proses mengamati (observing), menanya (questioning), mencoba (experimenting), menalar (associating), dan mengkomunikasikan (communication). 5M yang tertera dalam pendekatan saintifik akan memberikan dampak pada pengetahuan, sikap, dan keterampilan siswa.

Beberapa rangkaian kegiatan pembelajaran yang dilakukan guru-guru SD Negeri Serayu Yogyakarta, terlepas dari kesulitan dan kekurangannya, dapat dikatakan telah menjalankan amanat dari ketentuan Kurikulum 2013. Guru-guru SD Negeri Serayu Yogyakarta telah mengupayakan pembelajaran yang menuntut siswa berfikir sistematis dan kritis dalam upaya memecahkan masalah yang penyelesaiannya tidak mudah dilihat. Hal ini tampak pada kegiatan $5 \mathrm{M}$ dalam proses pembelajaran. Kegiatan ini sangat baik untuk perkembangan intelektual siswa.

Kendala yang muncul dalam pengamatan adalah beberapa guru, terutama guru senior (yang hampir pensiun) masih bersusah payah mentematikkan dan mensaintifik-kan setiap mata pelajaran. Hal tersebut dikarenakan usia ataupun pola pem- 
belajaran yang dilakukannya telah melekat, sehingga ketika terjadi perubahan (perubahan kurikulum), guru tersebut akan mengalami kesulitan.

\section{Kegiatan Penutup}

Kegiatan penutup yang dilakukan guru umumnya telah sesuai dengan ketentuan Kurikulum 2013. Guru menyimpulkan pembelajaran dengan menyajikan informasi-informasi spesifik. Selanjutnya guru memancing siswa siswa untuk bertanya maupun menyampaikan pendapat terhadap kegiatan pembelajaran yang telah diselenggarakan. Setelah itu, guru melakukan refleksi dari pembelajaran yang bertujuan agar siswa memahami dan mampu menerapkan ilmu pengetahuan yang telah didapatkan dalam kehidupan bermasyarakat.

Kegiatan penutup lainnya yang dilakukan oleh guru adalah dengan memberikan umpan balik terhadap proses dan hasil pembelajaran. Langkah yang dilakukan adalah dengan memberikan soal-soal berupa kuis. Pada prosesnya guru memberikan reward, yaitu siswa yang menjawab dengan benar akan diberikan kesempatan pulang terlebih dahulu. Guru melakukannya secara berkelompok maupun individu dalam pertemuan-pertemuan pembelajaran. Kegiatan ini memotivasi siswa untuk menjadi yang terbaik.

Sebelum berdoa, kegiatan penutup lainnya yang dilakukan guru adalah menyampaikan rencana pembelajaran pada pertemuan selanjutnya. Kegiatan ini bertujuan agar siswa mempersiapkan diri dan mengetahui pelajaran apa yang akan dipelajari selanjutnya. Konsentrasi siswa pada kegiatan ini biasanya sudah pudar, siswasiswa ingin bergegas pulang atau istirahat sehingga suasananya gaduh dan tidak terkontrol.

Secara umum, pelaksanaan pembelajaran Kurikulum 2013 di SD Negeri Serayu Yogyakarta telah berjalan dengan baik. Antusiasme yang diperlihatkan siswa dalam proses pembelajaran sangat terlihat selama pengamatan. Walaupun terdapat siswa yang pasif, mengganggu temannya, melakukan aktivitas yang lain, namun jumlahnya tidaklah begitu besar. Guru bahkan mendapat banyak solusi agar siswa tersebut dapat terlibat aktif dalam pembelajaran. Dengan kegiatan 5M yang ada dalam pendekatan saintifik, guru bisa memilih salah satunya guna menjadikan pembelajaran dapat berjalan multi arah. Sebagaimana dijelaskan Hosnan (2014, p. 34) yang mengatakan bahwa implementasi Kurikulum 2013 dalam pembelajaran yang dirancang sedemikian rupa agar peserta didik secara aktif mengonstruk konsep, hukum atau prinsip melalui tahapan-tahapan mengamati (untuk mengidentifikasi atau menemukan masalah), merumuskan masalah, mengajukan data, menarik kesimpulan dan mengomunikasikan konsep, hukum atau prinsip yang "ditemukan".

Kendala yang berarti dalam pelaksanaan pembelajaran hanyalah masalah waktu. Waktu yang sedikit menjadikan pembelajaran belum bisa dilaksanakan di luar ruang kelas. Untuk mengatasi hal tersebut, keberadaan media pembelajaran sangat membantu guru dalam mengkontekskan materi pembelajaran dengan kehidupan nyata. Maka dapat diambil kesimpulan bahwa pelaksanaan pembelajaran Kurikulum 2013 yang dilaksanakan oleh guruguru dan dukungan pihak sekolah serta orang tua siswa menjadikan proses pembelajaran berjalan dengan baik.

Penilaian Hasil Belajar

Hasil penelitian menunjukkan bahwa penilaian pembelajaran di SD Negeri Serayu Yogyakarta meliputi tiga kompetensi yang terdiri dari kompetensi sikap, kompetensi pengetahuan, dan kompetensi keterampilan. Ketiga kompetensi ini dianggap sama-sama penting, namun pada praktiknya di SD Negeri Serayu Yogyakarta kompetensi yang menonjol adalah kompetensi pengetahuan. Hal tersebut dikarenakan waktu penyelenggaraan Kurikulum 2013 masih tergolong baru sehingga diperlukan adaptasi dan pelatihan-pelatihan yang intensif terhadap guru-guru di SD Negeri Serayu Yogyakarta. 
Guru melakukan penilaian sikap dengan cara melihat langsung atau menggunakan teknik observasi. Guru memperhatikan bagaimana aktivitas siswa selama pembelajaran berlangsung. Pada awal tahun ajaran baru, guru biasanya melakukan beberapa observasi untuk keperluan identifikasi mengenai karakter-karakter peserta didiknya.

Beberapa cara yang dapat digunakan untuk menilai pengetahuan peserta didik, antara lain melalui tes tertulis, observasi terhadap diskusi, tanya jawab, dan percakapan, serta penugasan. Pada praktiknya guru hanya menggunakan instrumen tertulis untuk menilai pengetahuan siswa. Penilaian pengetahuan siswa juga dilakukan dengan pemberian Pekerjaan Rumah (PR). PR tersebut diperiksa dan kadang-kadang siswa diminta langsung menjawabnya di papan tulis. Siswa yang menjawab dengan benar akan mendapat nilai tambahan dari guru. Siswa yang mendapat nilai dibawah rata-rata akan mendapatkan ujian remedial untuk memperbaiki nilainya.

Penilaian yang digunakan untuk menilai keterampilan siswa adalah dengan menggunakan pinilaian proyek dan kinerja. Pelaksanaannya sendiri tidak menggunakan instrumen penilain melainkan menggunakan angka dengan rentang nilai 10100. Hal ini tentu saja mengabaikan pentingnya rubrik dan instrumen penilaian. Guru juga menggunakan portofolio untuk menilai keterampilan siswa. Portofolio tentu akan sangat membantu guru untuk melihat sejauh mana perkembangan siswa.

Dalam pertemuan rutin forum KKG juga dijelaskan dan didiskusikan mengenai mekanisme penilaian Kurikulum 2013. Secara konsep, penilaian Kurikulum 2013 dapat dikatakan sangat bagus, bahkan jika dibandingkan dengan negara-negara yang sistem pendidikannya bagus seperti Finlandia, konsep penilaian Kurikulum 2013 jauh lebih bagus. Akan tetapi, penilaian tersebut belum mampu direalisasikan dengan maksimal oleh guru-guru di SD Negeri Serayu Yogyakarta. Meskipun demikian, telaah dokumen mengenai instru- men penelitian yang dibuat oleh guru-guru di SD Negeri Serayu Yogyakarta sudah cukup baik.

Secara keseluruhan, berdasarkan tiga tahap pelaksanaan pembelajaran yang terdiri dari perencanaan pembelajaran, pelaksanaan pembelajaran, dan penilaian pembelajaran. SD Negeri Serayu Yogyakarta telah mampu melaksanakan pembelajaran Kurikulum 2013 dengan baik. Meskipun terdapat berbagai kendala dan hambatan dalam beberapa hal tertentu. Namun pendampingan dan pelatihan yang terus menerus dilakukan oleh pihak sekolah telah berkontribusi dalam mengurangi kendala dan hambatan-hambatan tersebut. Munculnya guru-guru instruktur di SD Negeri Serayu Yogyakarta menjadi bukti bahwa SD Negeri Serayu Yogyakarta telah dipercaya oleh pemerintah untuk menjadi sekolah percontohan (melaksanakan Kurikulum 2013) di tingkat sekolah dasar.

\section{Simpulan}

Berdasarkan pemaparan hasil penelitian dan pembahasan di atas, maka penelitian ini dapat disimpulkan sebagai berikut.

Pertama, perencanaan pembelajaran yang dilakukan melalui RPP yang dikembangkan oleh guru-guru di SD Negeri Serayu Yogyakarta telah disusun dengan baik berdasarkan tema dan sub tema tertentu yang mengacu pada silabus Kurikulum 2013. Penjabaran dalam RPP antara lain mencakup: (1) data sekolah, mata pelajaran, dan kelas/semester; (2) materi pokok; (3) alokasi waktu pembelajaran; (4) tujuan pembelajaran; (5) materi pembelajaran, metode pembelajaran; (6) media, alat dan sumber belajar; (7) langkah-langkah kegiatan pembelajaran; dan (8) penilaian.

Kedua, pelaksanaan pembelajaran yang dilakukan guru-guru meliputi kegiatan pendahuluan, kegiatan inti, dan kegiatan penutup. Dalam kegiatan pendahuluan, guru antara lain melakukan kegiatan berikut; (1) menyiapkan siswa secara psikis dan fisik untuk mengikuti pembelajaran; 
(2) memancing siswa untuk bertanya mengenai kegiatan yang telah dipelajari, (3) menyampaikan garis besar cakupan materi dan penjelasan tentang kegiatan yang akan dilakukan siswa untuk menyelesaikan permasalahan atau tugas. Sedangkan kegiatan inti yang dilakukan guru adalah dengan menggunakan pendekatan saintifik yang terdiri dari 5M. Kegiatan penutup yang dilakukan guru adalah menyimpulkan materi pembelajaran yang telah dibahas, melakukan refleksi, memberikan umpan balik terhadap proses dan hasil pembelajaran, membahas tugas kelompok dan individual, memberikan kuis, dan menyampaikan materi pembelajaran pada pertemuan selanjutnya.

Ketiga, penilaian pembelajaran yang dilakukan guru-guru di SD Negeri Serayu Yogyakarta antara lain menggunakan penilaian sikap, pengetahuan, dan keterampilan. Proses penilaiannya berupa tes dan non tes dalam bentuk tertulis maupun lisan, pengamatan kinerja, pengukuran sikap, penilaian hasil karya berupa tugas, proyek, penggunaan portofolio, dan penilaian diri.

Keempat, hambatan yang dihadapi dalam pelaksanaan Kurikulum 2013 antara lain: banyaknya materi namun alokasi waktunya sedikit, penilaian pembelajaran terlalu banyak yang mengakibatkan guru kerepotan, ketidaksiapan siswa menggunakan Kurikulum 2013 dikarenakan penerapan kurikulum yang berbeda sebelumnya, guru-guru belum sepenuhnya memahami konsep Kurikulum 2013. Sedangkan upaya dan faktor pendukung untuk mengatasi hambatan-hambatan tersebut antara lain dengan memaksimalkan forum KKG, mengadakan Les, dan bimbingan intensif oleh guru-guru kepada siswa. Selain itu, guruguru di SD Negeri Serayu Yogyakarta mendapat dukungan penuh dari wali murid.

Dengan selesainya penelitian ini, maka tentu ada beberapa temuan-temuan yang bisa dijadikan acuan agar pelaksanaan pembelajaran pada Kurikulum 2013 bisa diterapkan lebih baik. Oleh karena itu, peneliti ingin memberikan beberapa saran yaitu pertama, bagi Kepala Sekolah hendak- nya melakukan monitoring dan pelatihan yang berkelanjutan terhadap pelaksanaan pembelajaran Kurikulum 2013, agar kualitas penyelenggaraan pembelajaran di SD Negeri Serayu Yogyakarta dapat dipertahankan bahkan mampu ditingkatkan secara terus menerus. Kedua, Bagi guru-guru hendaknya terus meng-upgrade diri dengan belajar sehingga mampu mempertahankan performa, dan tidak terkejut dengan perubahan-perubahan yang terjadi dalam duania pendidikan. Ketiga, Sebagai pihak yang menentukan keputusan, hendaknya pelaksanaan pembelajaran menggunakan Kurikulum 2013 di SD Negeri Serayu Yogyakarta dapat didistribusikan sebagai sekolah percontohan untuk sekolah-sekolah yang belum melaksanakan pembelajaran menggunakan Kurikulum 2013 di tingkat sekolah dasar.

\section{Daftar Pustaka}

Fadlillah, M. (2014). Implementasi Kurikulum 2013 dalam pembelajaran SD/MI, SMP/MTS, dan SMA/MA. Yogyakarta: Ar-Ruzz Media.

Hosnan, M. (2014). Pendekatan saintifik dan kontekstua ldalam pembelajaran abad21: kunci sukses implementasi Kurikulum2013. Bogor: Ghalia Indonesia.

Mendikbud RI. Peraturan Menteri Pendidikan dan Kebudayaan Nomor 66 Tahun 2013 tentang Standar Penilaian (2013).

Mendikbud RI. Peraturan Menteri Pendidikan dan Kebudayaan Republik Indonesia Nomor 65 Tahun 2013 tentang Standar Proses Pendidikan Dasar dan Menengah (2013).

Prawiradilaga, D. S. (2012). Wawasan teknologi pendidikan. Jakarta: Kencana.

Tilaar, H. A. R., \& Nugroho, R. (2008). Kebijakan pendidikan: pengantar untuk memahami kebijakan pendidikan dan kebijakan pendidikan sebagai kebijakan publik. Yogyakarta: Pustaka Pelajar. 